Article

\title{
In Vitro and in Vivo Studies of the Inhibitory Effects of Emodin Isolated from Polygonum cuspidatum on Coxsakievirus $\mathbf{B}_{4}$
}

\author{
Zhao Liu ${ }^{1,2}$, Fei Wei ${ }^{1,3}$, Liang-Jun Chen ${ }^{1}$, Hai-Rong Xiong ${ }^{1}$, Yuan-Yuan Liu ${ }^{1}$, Fan Luo ${ }^{1}$, \\ Wei Hou ${ }^{1}$, Hong Xiao ${ }^{1}$ and Zhan-Qiu Yang ${ }^{1, *}$ \\ 1 State Key Laboratory of Virology, Institute of Medical Virology, School of Medicine, \\ Wuhan University, Wuhan 430071, China; E-Mails: liuzhao@mail.scuec.edu.cn (Z.L.); \\ simon1985511@gmail.com (F.W.); chenliangjun1122@163.com (L.-J.C.); \\ xionghairong@gmail.com (H.-R.X.); liuyuanyuan@126.com (Y.-Y.L.); \\ fanluo2011@whu.edu.cn (F.L.); houwei@whu.edu.cn (W.H.); xh@163.com (H.X.) \\ 2 College of Pharmacy, South-Central University for Nationalities, Wuhan 430074, China \\ 3 School of Basic Medicine, Hubei University of Chinese Medicine, Wuhan 430065, China \\ * Author to whom correspondence should be addressed; E-Mail: zqyang@whu.edu.cn; \\ Tel.: +86-27-6875-9136; Fax: +86-27-6875-8766.
}

Received: 29 July 2013; in revised form: 4 September 2013 / Accepted: 10 September 2013 / Published: 25 September 2013

\begin{abstract}
The lack of effective therapeutics for Coxsackievirus $\mathrm{B}_{4}\left(\mathrm{CVB}_{4}\right)$ infection underscores the importance of finding novel antiviral compounds. Emodin (1,3,8-trihydroxy-6-methylanthraquinone) is one of the natural anthraquinone derivatives obtained from the root and rhizome of Polygonum cuspidatum. In the present study, the possibility of using emodin as a potential antiviral to treat $\mathrm{CVB}_{4}$ infection was explored in vitro and in mice. Emodin reduced $\mathrm{CVB}_{4}$ entry and replication on Hep-2 cells in a concentration- and time-dependent manner, with a $50 \%$ effective concentration $\left(\mathrm{EC}_{50}\right)$ of $12.06 \mu \mathrm{M}$ and selectivity index (SI) of 5.08, respectively. The inhibitory effect of emodin for $\mathrm{CVB}_{4}$ entry and replication was further confirmed by a quantitative real time PCR (qPCR) assay. The results further showed that the mice orally treated with different dosages of emodin displayed a dose dependent increase of survival rate, body weight and prolonged mean time of death (MTD), accompanied by significantly decreased myocardial virus titers and pathologic scores/lesions. Moreover, emodin could inhibit $\mathrm{CVB}_{4}$-induced apoptosis in vitro and in vivo. Our results indicated that emodin could be used as potential antiviral in the post-exposure prophylaxis for $\mathrm{CVB}_{4}$ infection.
\end{abstract}


Keywords: emodin; Polygonum cuspidatum; inhibitory effect; Coxsakievirus $\mathrm{B}_{4}$

\section{Introduction}

Coxsackievirus $\mathrm{B}_{4}\left(\mathrm{CVB}_{4}\right)$ belongs to the genus Enterovirus, family Picornaviridae, and is one of six serotypes of the coxsackievirus $\mathrm{B}$ group. $\mathrm{CVB}_{4}$ can cause a broad range of diseases, such as myocarditis, pancreatitis, hepatitis, aseptic meningitis, meningoencephalitis, gastroenteritis, necrotizing enterocolitis, pneumonia and even death in neonates [1]. Moreover, clinical symptoms such as myopericarditis and pleurodynia (Bornholm disease) are still distinct and are associated only with $\mathrm{CVB}_{4}$ infections [2]. Until now, there are no enterovirus-specific vaccines or therapeutic agents available for clinical usage of $\mathrm{CVB}_{4}$ infection [3]. Current clinical therapeutic method and supportive treatment to reverse inflammation and alleviate the symptoms in many $\mathrm{CVB}_{4}$-infected patients has been still largely disappointing [4]. Although a great number of in vitro picornavirus replication inhibitors have been described, few of them have shown effectiveness in vivo [5], and none has been approved for clinical use to date. Ribavirin may act as a lethal mutagen via incorporation into the viral RNA genome. In vitro activity of ribavirin against enteroviruses has been demonstrated by several groups [6], and treatment of murine $\mathrm{CVB}_{3}$ myocarditis led to significantly decreased myocardial virus titer, inflammation, necrosis and myocardial calcification [7]. One side effect of ribavirin, however, is drug resistance [8], hemolytic anemia [9], and it is licensed only for the treatment of respiratory syncytial virus and hepatitis $\mathrm{C}$ virus infections [10]. Therefore, there is a need for an antiviral therapy which is effective for treating $\mathrm{CVB}_{4}$ infection.

Emodin (1,3,8-trihydroxy-6-methylanthraquinone) is an active component in the root and rhizome of Polygonum cuspidatum, which has been used in Traditional Chinese Medicine (TCM) for treating diseases like liver cirrhosis, diabetic nephropathy, atherosclerosis and tumours [11]. A number of pharmacological properties including anti-microbial, anti-inflammatory, antiviral, anticancer, immunosuppressive, and chemopreventive effects have been suggested [12,13]. Moreover, an increasing number of studies, including those from our laboratory, have extended the antiviral activity of emodin to many RNA and DNA viruses, enveloped and non-enveloped viruses, and pH-dependent and independent viruses, such as herpes simplex virus [14], hepatitis B virus [15], severe acute respiratory syndrome (SARS) coronavirus [16], etc. These findings are crucial for the understanding of the pharmacological properties of emodin, since despite extensive studies of its antiviral effects, the antiviral activity of emodin against $\mathrm{CVB}_{4}$ virus infections is still incompletely understood.

In this study, we systematically investigated the antiviral activity of emodin against $\mathrm{CVB}_{4}$ in vitro and in vivo. We demonstrated that emodin could inhibit the entry and replication of $\mathrm{CVB}_{4}$ in a concentration- and time-dependent manner. Emodin could also inhibit apoptosis induced by $\mathrm{CVB}_{4}$ infection. The in vivo study further showed that oral administration of emodin could significantly mitigate myocardial virus titers and pathologic lesions induced by $\mathrm{CVB}_{4}$ infection. These findings suggested that emodin may represent as a potential therapeutically effective agent for $\mathrm{CVB}_{4}$ infection. 


\section{Results and Discussion}

\subsection{In Vitro Experiments}

\subsubsection{Cytotoxicity of Emodin on HEp-2 Cells}

The extraction process and High Performance Liquid Chromatography (HPLC) analysis for emodin are shown in Figure 1a-c. The separation of emodin was carried out on an Acclaim 120-C18 column (4.6 $\mathrm{mm} \times 250 \mathrm{~mm}, 5 \mu \mathrm{m})$ with a mobile phase of methanol-water-0.1 phosphoric acid (85:15:0.05) under $30{ }^{\circ} \mathrm{C}$. The flow rate was set at $1.0 \mathrm{~mL} / \mathrm{min}$ and the detection wavelength was $289 \mathrm{~nm}$. The calibration curves of emodin showed good linearity over the $0.0075 \sim 0.0214 \mathrm{mg} / \mathrm{mL}$ range $(y=3197.9930 x+43.4724, r=0.9981)$. The emodin extracted from $50 \mathrm{~g}$ Polygonum cuspidatum is about $560.50 \pm 7.08 \mathrm{mg}$, or $(11.21 \pm 0.14) \%$ in terms of dried starting materials. The purity of emodin was $(70.69 \pm 0.32) \%$ in three independent experiments. We then tested the cytotoxicity of emodin on HEp-2 cells by the 3-(4,5-dimethylthiazol-2-yl)-2,5-diphenyltetrazolium bromide (MTT) assay. As shown in Table 1, the toxicity of emodin on HEp-2 cells was $(61.35 \pm 4.44) \mu \mathrm{M}$, and the highest non-toxic concentration was around $46.26 \mu \mathrm{M}$.

Figure 1. Isolation and identification of emodin (a) Extraction of emodin from Polygonum cuspidatum (b) HPLC analysis for emodin standard reference (c) HPLC analysis for emodin sample isolated from Polygonum cuspidatum (d) Chemical structure of emodin.

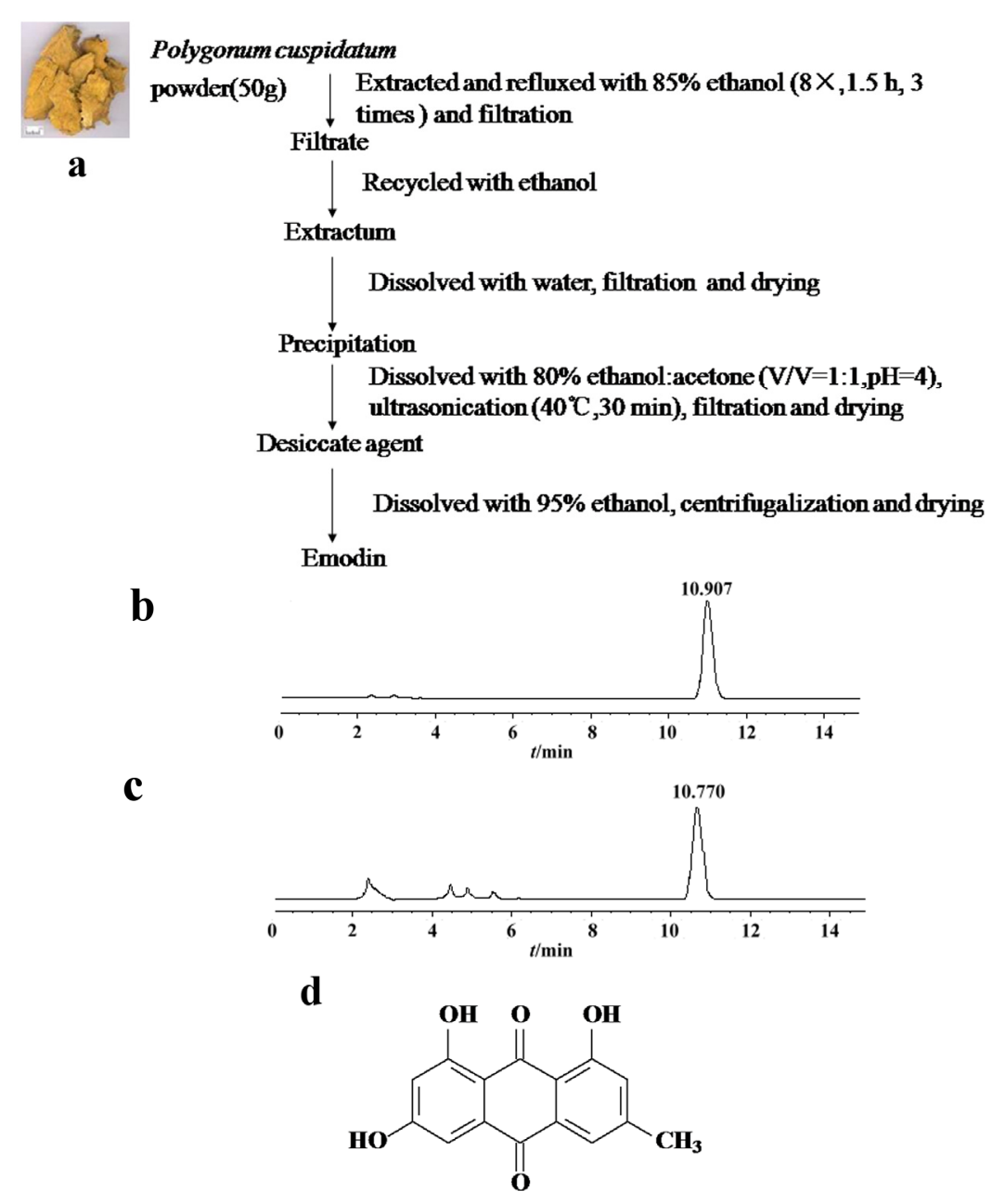


Table 1. Cytotoxicity and selectivity index of emodin on HEp-2 Cells.

\begin{tabular}{cccccc}
\hline \multirow{2}{*}{ Compound } & $\mathbf{C C}_{\mathbf{5 0}}(\boldsymbol{\mu M})$ & \multicolumn{2}{c}{$\mathbf{E C}_{\mathbf{5 0}}(\boldsymbol{\mu M})$} & \multicolumn{2}{c}{ Selectivity index } \\
\cline { 2 - 6 } & MTT & MTT & PRA & MTT & PRA \\
\hline Emodin & $61.35 \pm 4.40$ & $14.10 \pm 0.74$ & $12.06 \pm 1.85$ & $4.35 \pm 0.6$ & $5.09 \pm 0.3$ \\
Ribavirin & $2645.14 \pm 54.05$ & $629.99 \pm 1.64$ & $460.91 \pm 1.23$ & $4.20 \pm 0.7$ & $5.74 \pm 0.1$ \\
\hline
\end{tabular}

Cytotoxicity was determined by MTT assay. Antiviral activity was determined by MTT and PRA. Selectivity index $=\mathrm{CC}_{50}(50 \%$ cytotoxic concentration $) / \mathrm{EC}_{50}(50 \%$ effective concentration $)$. Emodin: $1 \mu \mathrm{M}=270.24 \mathrm{ng} / \mathrm{mL}$; Ribavirin: $1 \mu \mathrm{M}=244.21 \mathrm{ng} / \mathrm{mL}$.

\subsubsection{Inhibitory Effect of Emodin on $\mathrm{CVB}_{4}$ Infection}

Several reports have shown that emodin is active against multiple viral infections. We initially tested the ability of emodin to inhibit $\mathrm{CVB}_{4}$ entry and replication in HEp-2 cells. It has been reported that the $\mathrm{CC}_{50}$ of emodin on HepG2.2.15 cells was $150.46 \mu \mathrm{M}$. The $\mathrm{IC}_{50}$ against $\mathrm{HBV}$ was $77.71 \mu \mathrm{M}$ [17]. Cells were first infected with $\mathrm{CVB}_{4}$ and then treated with different concentrations of emodin. The virus-induced cytopathic effect (CPE) was delayed dramatically by emodin in a concentration-dependent manner (Figure 2a). As shown in Table 1, the $\mathrm{EC}_{50}$ of emodin determined by the MTT and plaque reduction assay (PRA) were $14.10 \pm 0.74 \mu \mathrm{M}$ and $12.06 \pm 1.85 \mu \mathrm{M}$, respectively. The selectivity indexes (SI) of emodin evaluated by MTT and PRA were $4.35 \pm 0.6$ and $5.09 \pm 0.3$, respectively. The inhibitory effect of emodin against $\mathrm{CVB}_{4}$ infection was equivalent to that of the conventional antiviral ribavirin. There was no significant difference of SI between emodin-treated group and ribavirin-treated group $(p>0.05)$. To determine whether the inhibition of the $\mathrm{CVB}_{4}$ entry and replication by emodin was also time dependent, the compound was added at indicated times $(0,2,4,8,12 \mathrm{~h}$ postinfection). The maximum inhibitory rate could be observed when emodin was added at $0-4 \mathrm{~h}$ postinfection when placed at $37{ }^{\circ} \mathrm{C}$ after inoculation (Figure 2b). Published research by several other investigators has indicated that the mechanism of antiviral activity of emodin derived from other sources relies on direct inactivation of infectious viral particles $[18,19]$. To investigate if emodin had a direct inactivation effect on $\mathrm{CVB}_{4}$ particles, varying concentrations of emodin were incubated with $\mathrm{CVB}_{4}$ for indicated times prior to inoculation on cells. However, no virucidal effect could be observed in our study, with the maximum inhibitory rate of emodin in virucidal assay being only about $(8.26 \pm 0.3) \%$. No inhibitory activity was observed when cells were pre-incubated with various concentrations of emodin, since the inhibitory rate was only $(7.35 \pm 0.2) \% \sim(9.56 \pm 0.5) \%$ at each dosage. There was no significant difference between emodin-treated groups and the virus control group in the direct inactivation and pre-incubation assay $(p>0.05)$. Quantitative real time PCR (qPCR) was then used to evaluate $\mathrm{CVB}_{4}$ RNA levels. Figure $2 \mathrm{c}$ summarizes the number of copies obtained from different treatments after normalizing to glyceraldehyde-3-phosphate dehydrogenase (GAPDH). It was observed that $\mathrm{CVB}_{4}$ copies in the 37, $18.5,9.0 \mu \mathrm{M}$ emodin group expressed $0.77,0.55$ and 0.40 -fold lower than the virus control group $(p<0.01)$, a result that corroborates the dose dependent inhibitory effect of emodin against $\mathrm{CVB}_{4}$ infection. 
Figure 2. Antiviral activity of emodin against $\mathrm{CVB}_{4}$ infection. (a) MTT assay was performed to determine antiviral effect of emodin on HEp-2 cells. $\mathrm{NC}$ and $\mathrm{VC}$ indicate normal control and viral control. (b) Time-of-addition assay. HEp-2 cells were seeded into 12-well culture plates and were infected with $\mathrm{CVB}_{4}$ for $1 \mathrm{~h}$ at $4{ }^{\circ} \mathrm{C}$ to allow virus binding but not virus entry, the infected cells were treated or mock treated with emodin $(37 \mu \mathrm{M})$ or ribavirin $(512 \mu \mathrm{M})$ or $2 \%$ test medium at the indicated times intervals of $0,2,4,8$, and $12 \mathrm{~h}$ postinfection. Virus titers were determined by plaque assay. The data are expressed as the mean $\pm \mathrm{SD}$ of three independent experiments. $* * p<0.01$ versus virus control. (c) Dose-response columns for emodin treatment in HEp-2 cells after drug incubation as determined by qPCR assay. The $\mathrm{CVB}_{4}$ RNA levels were normalized to that of the housekeeping gene GAPDH. Each data point represents the mean \pm standard deviation from three independent experiments. $* * p<0.01$ versus virus control.

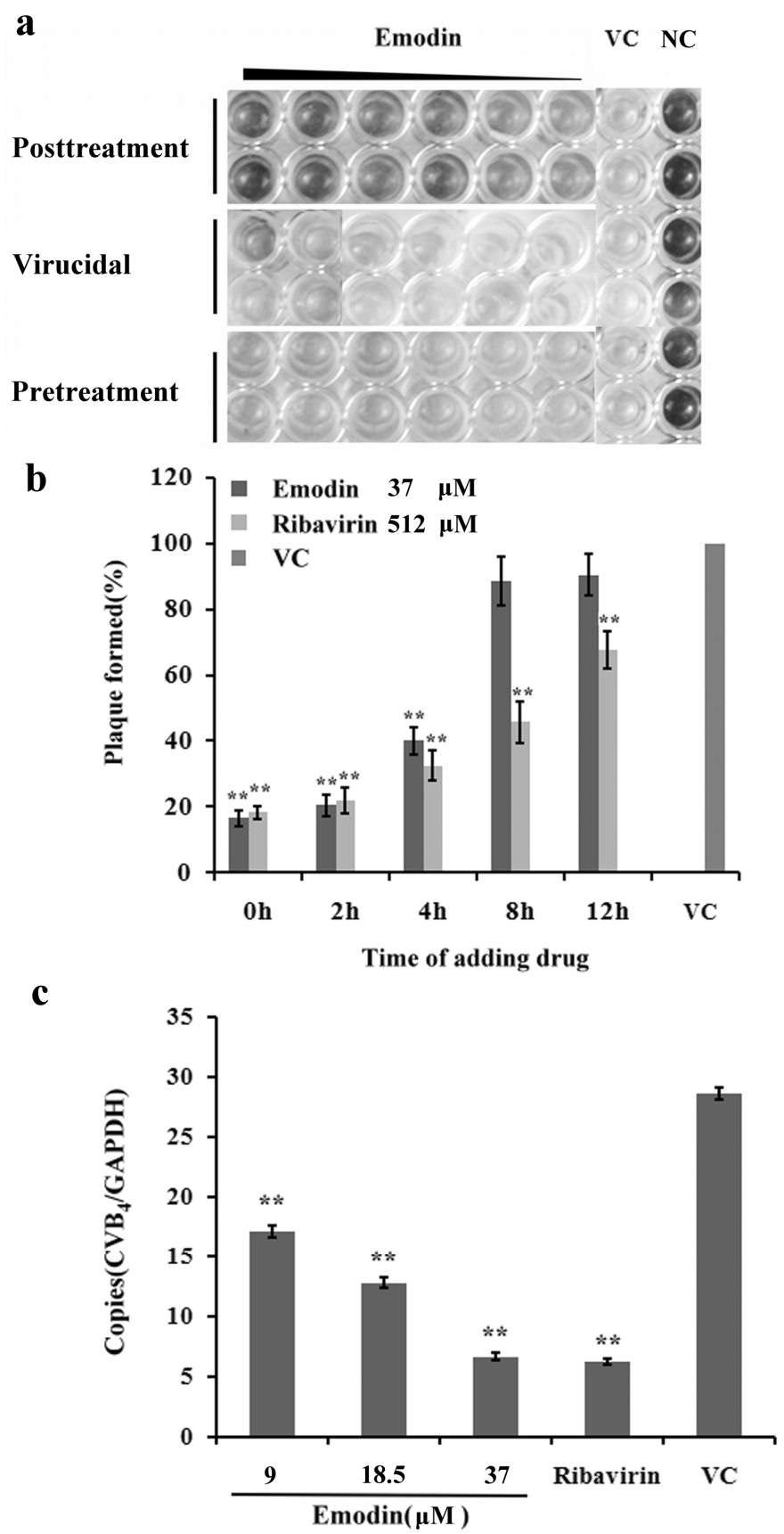




\subsubsection{Emodin Mitigates $\mathrm{CVB}_{4}$-Induced Apoptosis in Vitro}

Previous data showed that $\mathrm{CVB}_{4}$ could induce apoptosis in primary neurons. To assess the hypothesis that emodin may attenuate the ongoing cell death or apoptosis in HEp-2 cells after $\mathrm{CVB}_{4}$ infection, HEp-2 cells infected with $\mathrm{CVB}_{4}$ were incubated with $18.5,9 \mu \mathrm{M}$ emodin or $512 \mu \mathrm{M}$ ribavirin and harvested to evaluate apoptotic changes. The results are summarized in Figure 3. The number of cells with Annexin-V binding was almost equal, but the apoptosis rate was significantly increased in cells infected with $\mathrm{CVB}_{4}$ virus at $48 \mathrm{~h}$ postinfection. The apoptosis rate in cells treated with emodin and ribavirin were significantly lower than the infected controls $(p<0.01)$, suggesting that emodin can inhibit apoptosis induced by $\mathrm{CVB}_{4}$. There were no differences between the $18.5 \mu \mathrm{M}$ emodin and $512 \mu \mathrm{M}$ ribavirin $(p>0.05)$ treated groups.

Figure 3. Effects of emodin on apoptosis in HEp-2 cells induced by $\mathrm{CVB}_{4}$ infection. (a) Hep-2 cells were infected with $\mathrm{CVB}_{4}$ and incubated with emodin $(18.5,9 \mu \mathrm{M})$ or ribavirin $(512 \mu \mathrm{M})$ for $48 \mathrm{~h}$, stained with Annexin-V and PI, and analyzed by flow cytometry. (b) Column bar graph of apoptosis. $* * p<0.01$ versus virus control.

a
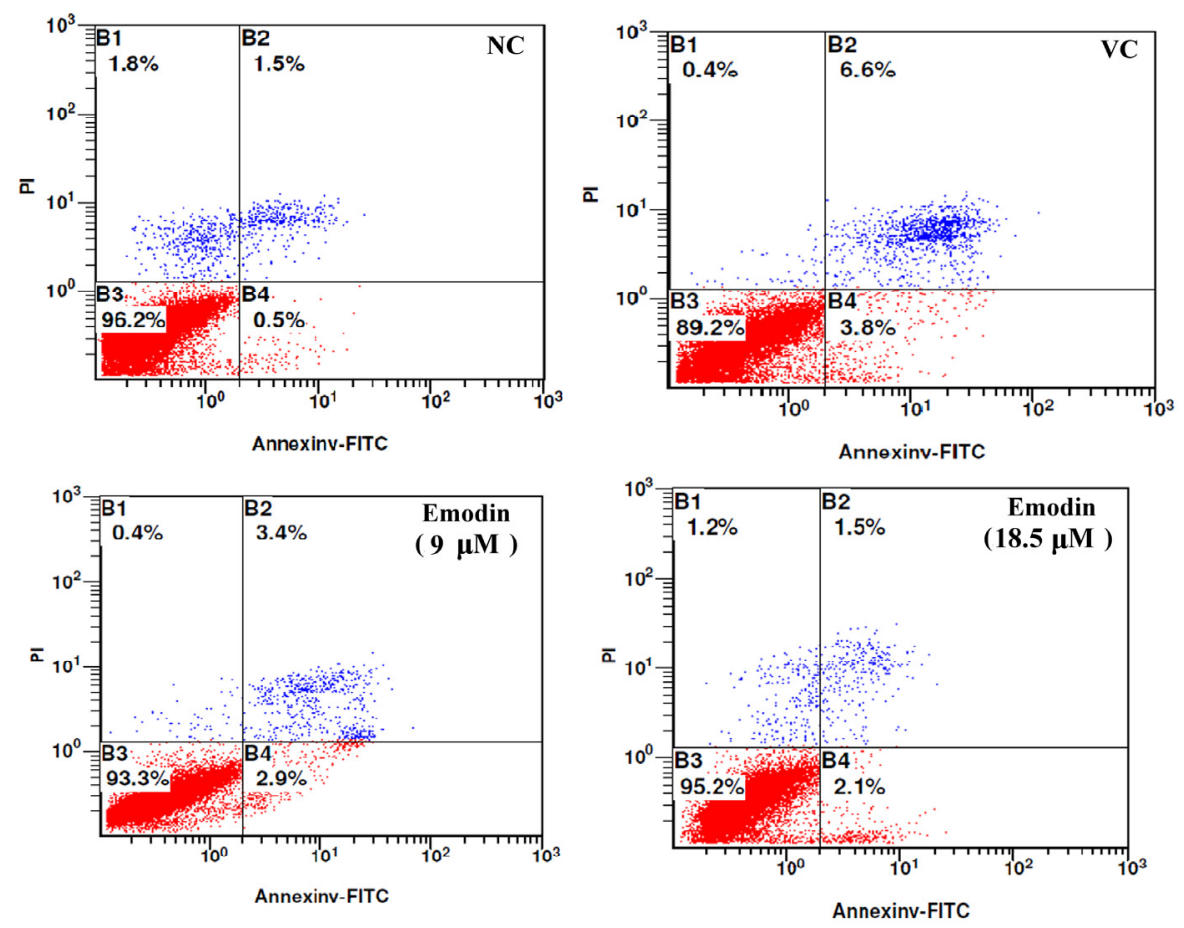

b
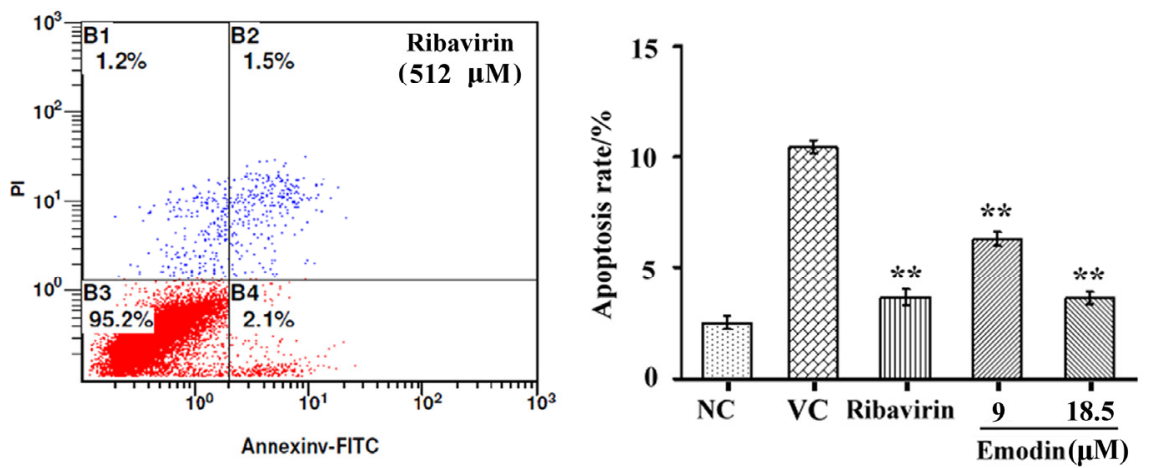


\section{2. in Vivo Experiments}

\subsubsection{Emodin Increases the Survival Rate of $\mathrm{CVB}_{4}$ Infected Mice}

The median lethal dose $\left(\mathrm{LD}_{50}\right)$ of emodin was determined prior to virus inoculation. Death rate for oral gavage of emodin at the dosages of $2.00,1.00,0.50,0.25,0.12 \mathrm{~g} / \mathrm{kg} / \mathrm{d}$ for $10 \mathrm{~d}$ were $100 \%, 83 \%$, $33 \%, 8 \%$ and $0 \%$, respectively. $\mathrm{LD}_{50}$ of emodin was calculated as $0.58 \mathrm{~g} / \mathrm{kg} / \mathrm{d}$. The pharmacokinetics of emodin and ribavirin were determined by HPLC analysis, respectively. The pharmacokinetic model of emodin and ribavirin fits well with the two-compartment model. Plasma levels of emodin (30 mg/kg/d) rise to the maximum 10 min after administration, with $\mathrm{C}_{\max }$ at $21.6 \pm 2.23 \mu \mathrm{M}$. The half life is $11.5 \mathrm{~h}$. Plasma concentration of ribavirin rises to the maximum 12 min after administration, with $\mathrm{C}_{\max }$ at $5.357 \pm 0.312 \mu \mathrm{M}$. The half life is $12 \mathrm{~h}$.

Clinical signs of murine $\mathrm{CVB}_{4}$ infection that generally appeared $3 \mathrm{~d}$ post-infection were observed in some mice, especially in the virus control. Changes in behavior, such as transient states of hyperactivity and weight loss, accompanied by hunched posture and progressively diminishing vitality were observed. Compared with the placebo-treated animals, emodin-treated animals died later and the appearance of clinical signs was delayed in a dose-dependent manner.

As shown in Figure 4a, the survival rate of the $30 \mathrm{mg} / \mathrm{kg} / \mathrm{d}(9 / 15,60.0 \%, p<0.01), 15 \mathrm{mg} / \mathrm{kg} / \mathrm{d}$ $(8 / 15,55.33 \%, p<0.01)$ and $7.5 \mathrm{mg} / \mathrm{kg} / \mathrm{d}(4 / 15,26.67 \%, p<0.01)$ groups increased dramatically compared to the virus control group. The $30 \mathrm{mg} / \mathrm{kg} / \mathrm{d}$ and $15 \mathrm{mg} / \mathrm{kg} / \mathrm{d}$ emodin-treated groups showed no significant difference with the ribavirin group $(10 / 15,67.67 \%, p>0.05)$ and the $30 \mathrm{mg} / \mathrm{kg} / \mathrm{d}$ group showed a better survival rate than $7.5 \mathrm{mg} / \mathrm{kg} / \mathrm{d}$ group $(p<0.05)$. In Figure $4 \mathrm{~b}$, compared to virus group $(8.47 \pm 0.87 \mathrm{~d})$, MTD was prolonged in treatment of emodin at the dosage of $30 \mathrm{mg} / \mathrm{kg} / \mathrm{d}(13.27 \pm 1.08 \mathrm{~d}$, $p<0.01), 15 \mathrm{mg} / \mathrm{kg} / \mathrm{d}$ group $(12.23 \pm 1.10 \mathrm{~d}, p<0.01)$ and $7.5 \mathrm{mg} / \mathrm{kg} / \mathrm{d}$ group $(10.4 \pm 0.56 \mathrm{~d}, p<0.05)$. MTD showed no differences among $30 \mathrm{mg} / \mathrm{kg} / \mathrm{d}, 15 \mathrm{mg} / \mathrm{kg} / \mathrm{d}$ emodin-treated groups and ribavirin control $(13.33 \pm 1.43, p>0.05)$.

The body weights of the animals were also measured for 14 consecutive days (Figure 4c). Mice infected with virus without treatment exhibited an obvious weight loss compared to the uninfected mice $(p<0.01)$. However, mice treated with emodin maintained relatively steady weights and showed less weight loss throughout the infection. The groups treated with $30 \mathrm{mg} / \mathrm{kg} / \mathrm{d}$ and $15 \mathrm{mg} / \mathrm{kg} / \mathrm{d}$ emodin showed no differences with the ribavirin-treated control after $8 \mathrm{~d}(p>0.05)$.

\subsubsection{Emodin Alleviates the Myocardial Lesions Induced by $\mathrm{CVB}_{4}$ Infection}

The heart weight/body weight $(\mathrm{HW} / \mathrm{BW}$ ) ratio in the infected control group on days 7 and 14 were significantly increased compared with those in the normal control group. However, the ratio decreased dramatically in mice treated with emodin at all dosages $(p<0.01$ at 30 and $15 \mathrm{mg} / \mathrm{kg} / \mathrm{d}, p<0.05$ at $7.5 \mathrm{mg} / \mathrm{kg} / \mathrm{d}$, Figure $5 \mathrm{a}$ ). The changes of the virus titers in heart of the $\mathrm{CVB}_{4}$ infected mice from different groups at day 7 and 14 are shown in Figures 5b,c. Oral gavage of emodin at the dosages of 30 and $15 \mathrm{mg} / \mathrm{kg} / \mathrm{d}$ significantly reduced the virus titers in the heart homogenates compared to the virus control group $(p<0.05)$. We further examined the myocardial lesions and evaluated the pathologic score in $\mathrm{BALB} / \mathrm{c}$ mice treated with different dosage of emodin. Compared with the infected control group, the 
damage of myocardium was relieved and scores of necrosis and infiltration were decreased significantly with emodin treatment at all dosages $14 \mathrm{~d}$ after infection (Table 2 and Figure 6).

Figure 4. Mortality following $\mathrm{CVB}_{4}$ infection and emodin treatment in mice. Mice challenged with $10 \mathrm{LD}_{50}$ of $\mathrm{CVB}_{4}$ were orally administered with $30 \mathrm{mg} / \mathrm{kg} / \mathrm{d}, 15 \mathrm{mg} / \mathrm{kg} / \mathrm{d}$, and $7.5 \mathrm{mg} / \mathrm{kg} / \mathrm{d}$ emodin, respectively. $0.9 \%$ saline was used in viral control and normal control group. The survival rate (a), mean time to death (b), and body weight (c) of each group were determined. Statistical significance is determined by Kaplan-Meier Log Rank Test, $* * p<0.01, * p<0.05 v s$. infected control group.

$\mathbf{a}$

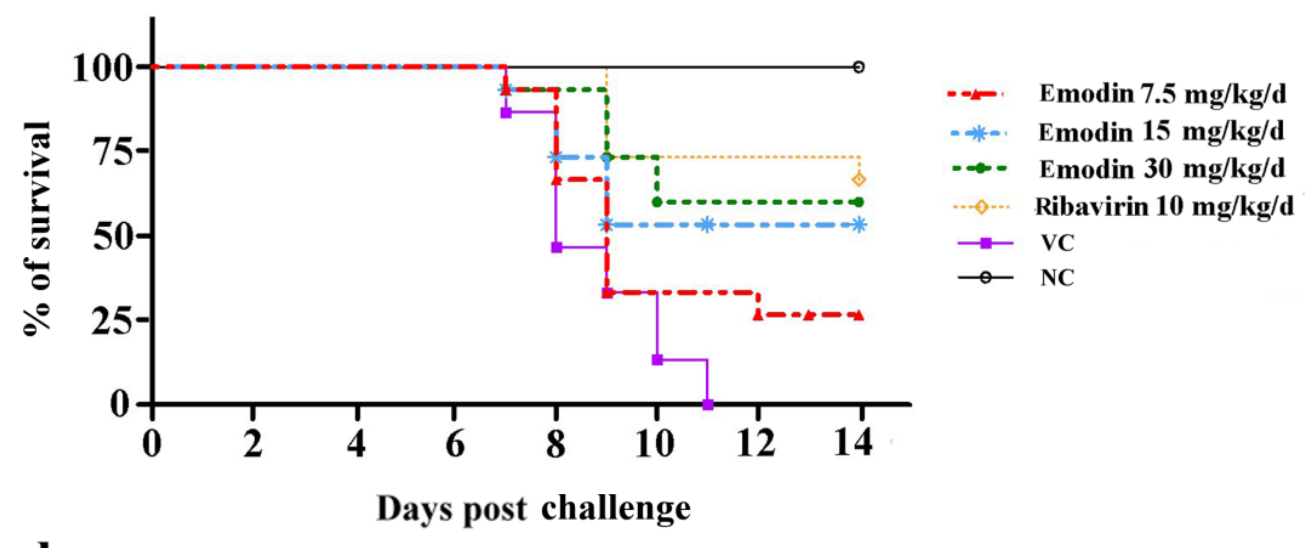

b

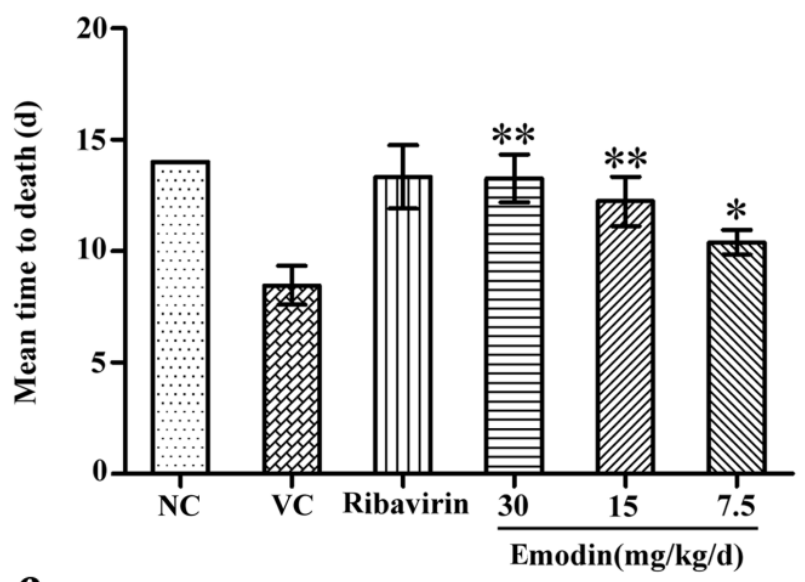

c

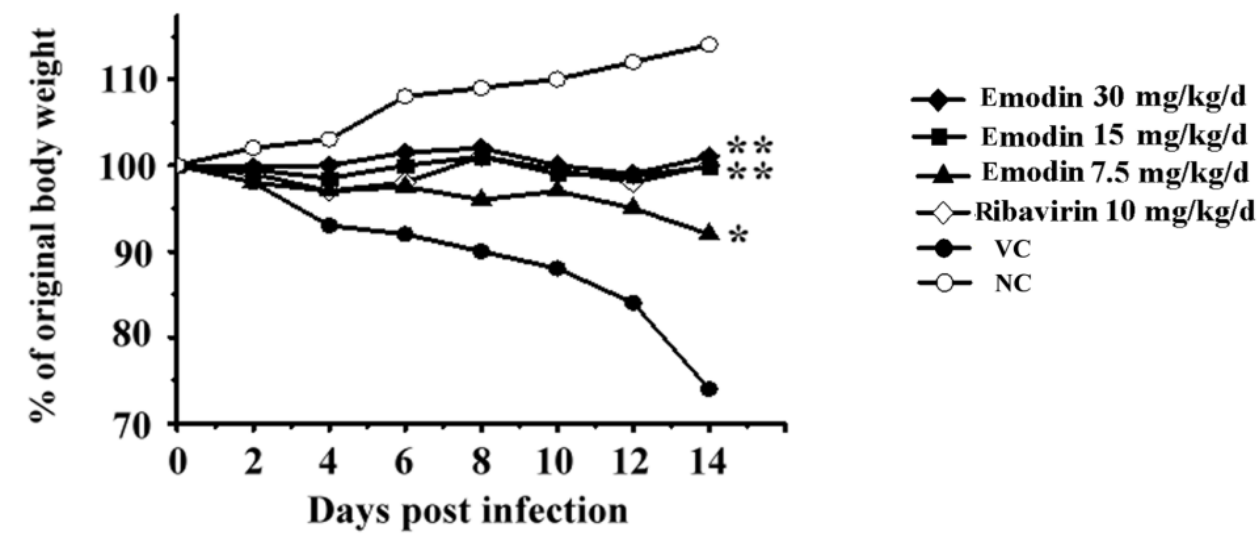


Figure 5. Emodin treatment alleviates myocardial inflammation and reduced apoptosis-related genes expression in $\mathrm{CVB}_{4}$ infected mice. (a) Mice were sacrificed at indicated times. Body weight $(\mathrm{BW} / \mathrm{g})$ and heart weight $(\mathrm{HW} / \mathrm{mg})$ of each group was measured to calculate the heart to body weight ratio (HW/BW) for each group. (b, c) Heart virus titers were determined by plaque assay on the 7th day (b) and 14th day (c) postinfection. (d) The mRNA expression of caspase-3 and bcl-2 in treated and control groups were determined by qPCR assay. ${ }^{* *} p<0.01, * p<0.05 v$ s. infected control group.
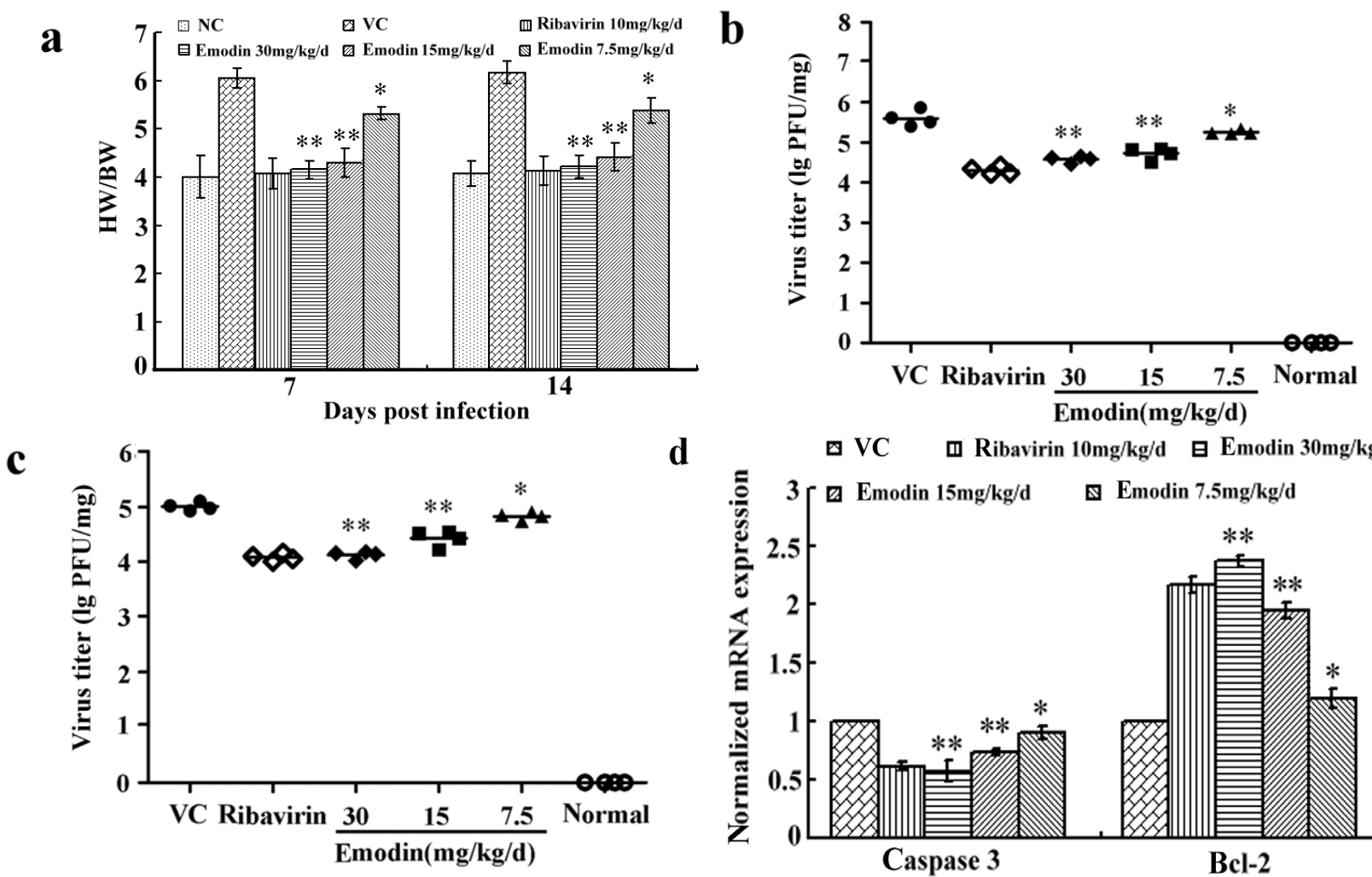

d

口 VC U Ribavirin $10 \mathrm{mg} / \mathrm{kg} / \mathrm{d}$ 日 Emodin $30 \mathrm{mg} / \mathrm{kg} / \mathrm{d}$

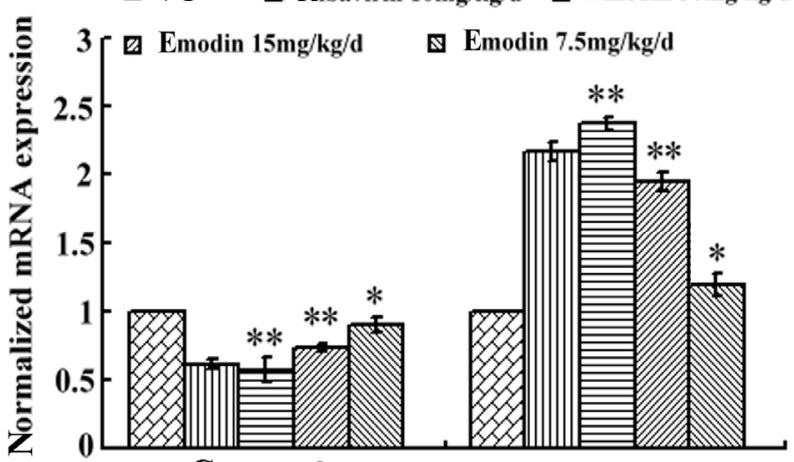

Caspase 3

Bcl-2

Table 2. Effects of emodin on pathologic score in BALB/c mice infected by $\mathrm{CVB}_{4}$ at 7 and $14 \mathrm{~d}$ postinfection.

\begin{tabular}{ccccc}
\hline & \multicolumn{4}{c}{ Pathologic score (means \pm S.D.) } \\
\cline { 2 - 5 } Group & \multicolumn{2}{c}{ 7 day } & 14 day \\
\cline { 2 - 5 } & $\begin{array}{c}\text { Inflammatory } \\
\text { infiltration }\end{array}$ & Necrosis & $\begin{array}{c}\text { Inflammatory } \\
\text { Infiltration }\end{array}$ & Necrosis \\
\hline $\mathrm{NC}$ & $0.93 \pm 0.67$ & $0.90 \pm 0.58$ & $0.85 \pm 0.64$ & $0.80 \pm 0.48$ \\
$\mathrm{VC}$ & $3.04 \pm 0.29$ & $3.01 \pm 0.45$ & $3.18 \pm 0.44$ & $2.94 \pm 0.39$ \\
Ribavirin $10 \mathrm{mg} / \mathrm{kg} / \mathrm{d}$ & $1.19 \pm 0.17 * *$ & $1.13 \pm 0.25 * *$ & $1.12 \pm 0.46 * *$ & $1.05 \pm 0.25 * *$ \\
Emodin $30 \mathrm{mg} / \mathrm{kg} / \mathrm{d}$ & $1.15 \pm 0.24 * *$ & $1.07 \pm 0.31 * *$ & $1.07 \pm 0.33 * *$ & $0.99 \pm 0.25 * *$ \\
Emodin $15 \mathrm{mg} / \mathrm{kg} / \mathrm{d}$ & $1.49 \pm 0.22 * *$ & $1.39 \pm 0.39 * *$ & $1.41 \pm 0.20 * *$ & $1.33 \pm 0.30 * *$ \\
Emodin $7.5 \mathrm{mg} / \mathrm{kg} / \mathrm{d}$ & $2.08 \pm 0.12 *$ & $2.01 \pm 0.16 *$ & $2.00 \pm 0.22$ & $1.98 \pm 0.23 *$ \\
\hline & $* * p<0.01, p<0.05 v s$. infected control group. &
\end{tabular}

\subsubsection{Emodin Can Alter Transcription and Protein Levels of Apoptosis-Related Genes in Vivo}

We then assessed the expression of two apoptosis-related genes, caspase- 3 and bcl-2 at both mRNA and protein levels, in order to investigate the effect of emodin on apoptosis-related genes in vivo at $14 \mathrm{~d}$ 
postinfection. Treated groups were compared against those of controls using the relative quantification $\left(2^{-} \Delta \Delta \mathrm{T}\right)$ method. The mRNA expression levels of caspase-3 in $30,15,7.5 \mathrm{mg} / \mathrm{kg} / \mathrm{d}$ emodin treated groups were $0.57,0.73,0.9$-fold and the bcl-2 levels were $2.37,1.95,1.18$-fold, respectively, with respect to the expression in virus control (Figure 5d). Therefore, emodin treatment could reduce the amount of caspase-3 mRNA levels, while it dramatically increased the bcl-2 mRNA levels compared to $\mathrm{CVB}_{4}$-infected control $(p<0.01$ at 30 and $15 \mathrm{mg} / \mathrm{kg} / \mathrm{d}, p<0.05$ at $7.5 \mathrm{mg} / \mathrm{kg} / \mathrm{d})$. The group treated with $30 \mathrm{mg} / \mathrm{kg} / \mathrm{d}$ emodin showed no difference with the ribavirin-treated group ( $p>0.05,0.61$-fold caspase-3 and 2.17-fold bcl-2 of virus control). The heart tissues were also analyzed to determine the expression of apoptosis-related proteins by western blot. As shown in Figure 7b, treatment with emodin $(30 \mathrm{mg} / \mathrm{kg} / \mathrm{d})$ notably decreased the expression levels of caspase- 3 while it up-regulated the expression of anti-apoptosis protein bcl-2 compared with nontreated infected groups. These results suggested that emodin could alter the transcription levels of apoptosis-related genes in vivo.

Figure 6. Emodin treatment ameliorates $\mathrm{CVB}_{4}$ induced heart lesions. Photomicrographs of H\&E-stained paraffin sections generated from (a) normal control (b) viral control (c) ribavirin $(10 \mathrm{mg} / \mathrm{kg} / \mathrm{d})(\mathbf{d})$ emodin $(30 \mathrm{mg} / \mathrm{kg} / \mathrm{d})(\mathbf{e})$ emodin $(15 \mathrm{mg} / \mathrm{kg} / \mathrm{d})(\mathbf{f})$ emodin $(7.5 \mathrm{mg} / \mathrm{kg} / \mathrm{d})$. Sections from viral control displayed mononuclear cell inflammation and the appearance of multiple foci in necrotic cardiomyocytes. In groups treated with emodin or ribavirin, the lesions of the myocardium were relieved and the area of necrosis and inflammatory infiltrates was significantly decreased compared with non-treated, infected animals.
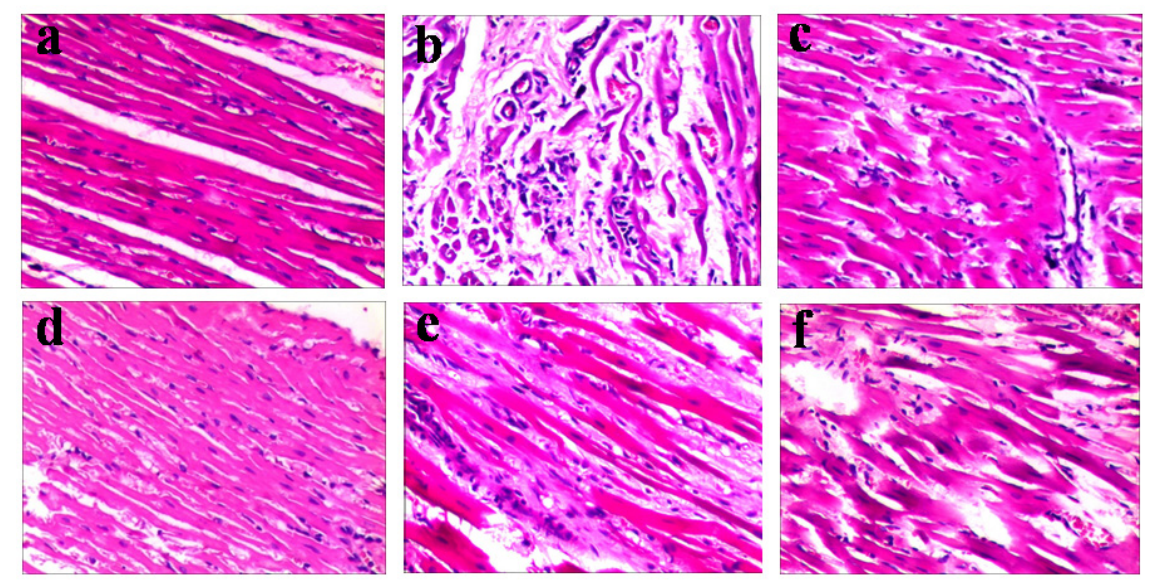

Figure 7. Detection of caspase-3 and Bcl-2 expression in emodin-treated (30, $7.5 \mathrm{mg} / \mathrm{kg} / \mathrm{d})$, ribavirin $(10 \mathrm{mg} / \mathrm{kg} / \mathrm{d})$ and virus control groups by western blot analysis. GAPDH was examined to normalize any differences in loading.

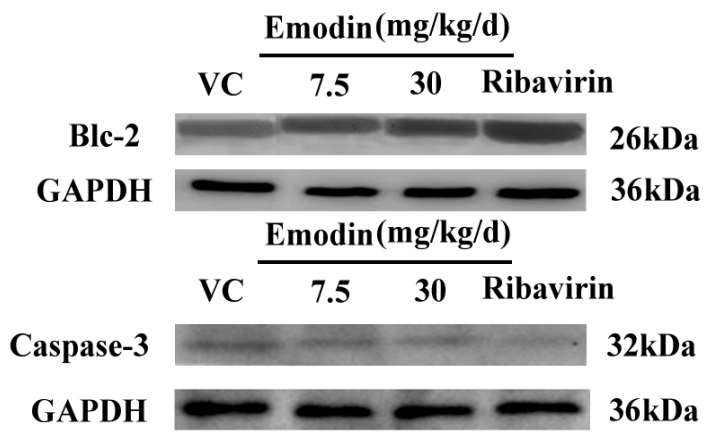




\section{Experimental}

\subsection{Extraction and Isolation of Emodin}

Polygonum cuspidatum was purchased from Hubei Medicinal Material Company (Wuhan, China). The identification and authenticity of the plant was confirmed by a professional medicinal plant expert, Prof. Keli Chen, Department of Plant Chemistry, Hubei University of Traditional Medicine (Hubei, China). The extraction under reflux scheme is shown in Figure 1a. The quantity of emodin was determined by HPLC (Dionex Ultimate 3000, Sunnyvale, CA, USA) analysis. The emodin was identified by NMR (AM-300, Bruker, Billerica, MA, USA) as follows: ${ }^{1} \mathrm{H}-\mathrm{NMR}\left(300 \mathrm{MHz}, \mathrm{DMSO}-\mathrm{d}_{6}\right)$ $\delta: 7.08$ (1H, s, H-2), 7.50 (1H, s, H-4), $7.22(1 \mathrm{H}, \mathrm{d}, J=1.0 \mathrm{~Hz}, \mathrm{H}-5), 6.60$ (1H, d, $J=1.0 \mathrm{~Hz}, \mathrm{H}-7), 2.35$ $\left(3 \mathrm{H}, \mathrm{s}, \mathrm{CH}_{3}\right), 12.09,12.16\left(1 \mathrm{H}\right.$ each, s, OH) ${ }^{13} \mathrm{C}-\mathrm{NMR}\left(75 \mathrm{MHz}, \mathrm{DMSO}-\mathrm{d}_{6}\right) \delta: 164.84(\mathrm{C}-1), 120.05$ (C-2), 147.60 (C-3), 123.59 (C-4), 109.32 (C-5), 161.72 (C-6), 108.30 (C-7), 166.38(C-8), 189.85 (C-9), 181.50 (C-10), 133.42 (C-4a), 108.71 (C-8a), 113.15 (C-9a), 134.76 (C-10a), $22.17\left(\mathrm{CH}_{3}\right)$.

\subsection{Experiments in Vitro}

\subsubsection{Cells and Virus Stocks}

HEp-2 (human laryngeal carcinoma) cells were routinely grown in DMEM (Dulbecco's modified Eagle's medium) supplemented with 10\% fetal calf serum (Gibco, Langley, OK, USA), penicillin (100 IU/mL), streptomycin $(100 \mu \mathrm{g} / \mathrm{mL})$ and $0.1 \%$ L-glutamine. Coxsackie virus $\mathrm{B}_{4}$ strain was maintained in our laboratory and propagated in HEp-2 cells. The virus titer was estimated from cytopathogenicity of cells induced by viral infection and expressed as $50 \%$ tissue culture infectious doses $\left(\mathrm{TCID}_{50}\right)[20]$.

\subsubsection{Evaluation of Cytotoxicity}

The MTT cell proliferation assay was performed as described previously [21]. Briefly, cells were seeded in 96-well plates and cultured at $37{ }^{\circ} \mathrm{C}$ in an atmosphere of $5 \% \mathrm{CO}_{2}$ incubator for $24 \mathrm{~h}$ until $80 \% \sim 90 \%$ confluent monolayer were formed. After removal of the growth medium, two-fold serial dilutions of emodin and ribavirin (Tianjing Pharmaceutical Co. Ltd., Tianjing, China) were added and incubated for $72 \mathrm{~h}$. Then the culture medium was removed and the $50 \mu \mathrm{L}$ thiazolyl blue tetrazolium bromide solution (Sigma-Aldrich, St. Louis, MO, USA) was added and incubated for 2 4 h until the purple precipitate was fully visible. The formazan was dissolved in dimethyl sulfoxide (DMSO), and then quantitated in a conventional microplate reader at $490 \mathrm{~nm}$ according to the manufacturer's protocol. The toxic dose for $50 \%$ cell death $\left(\mathrm{CC}_{50}\right)$ of emodin were calculated from dose-response curves by optical density $\left(\mathrm{OD}_{\text {of treated cells }} / \mathrm{OD}_{\text {of untreated cells }}\right) \times 100$. All assays were performed in triplicate.

\subsubsection{Drug Treatment after Infection}

HEp-2 cells grown in 96-wells cell culture plate were challenged with $100 \mathrm{TCID}_{50} \mathrm{CVB}_{4}$ for $1 \mathrm{~h}$. After thoroughly washing unbound virus, serial two-fold dilutions of emodin $(10,5,2.5,1.25,0.6,0.3 \mu \mathrm{g} / \mathrm{mL})$ were added to each well. The development of CPE was monitored daily by light microscopy until the 
virus-infected, untreated cells showed CPE up to $80 \%$. At this time point, the antiviral activity of each concentration was measured by an MTT assay. The percent of inhibition was calculated by the following formula:

Percent of inhibition $(\%)=\left(\mathrm{OD}_{\text {compound treated group }}-\mathrm{OD}_{\text {virus control }}\right) /\left(\mathrm{OD}_{\text {normal control }}-\mathrm{OD}_{\text {virus control }}\right) \times 100 \%$.

The $\mathrm{EC}_{50}$ was calculated by regression analysis of the dose-inhibition relationship using SPSS 13.0. The selectivity index (SI) was evaluated with the following formula: $\mathrm{SI}=\mathrm{CC}_{50} / \mathrm{EC}_{50}$.

\subsubsection{Virucidal Assay}

The direct effect of emodin on $\mathrm{CVB}_{4}$ infectivity was evaluated according to the protocols described by Xiong [22] et al. with slight modifications. Briefly, viral suspensions containing $100 \mathrm{TCID}_{50}$ of $\mathrm{CVB}_{4}$ were either incubated with an equal volume of medium containing different concentrations of emodin $(10,5,2.5,1.25,0.6,0.3 \mu \mathrm{g} / \mathrm{mL})$ or with drug-free vehicle at $4{ }^{\circ} \mathrm{C}$ for $2-6 \mathrm{~h}$, respectively. After $1 \mathrm{~h}$ adsorption, the mixed suspensions were removed. The cell monolayers were rinsed carefully with phosphate buffered solution (PBS) and maintained in test medium at $37^{\circ} \mathrm{C}$ in a humidified atmosphere for $72 \mathrm{~h}$. The virucidal effect was determined by an MTT assay following the procedures described above.

\subsubsection{Drug Treatment before Infection}

Confluent HEp-2 monolayer cells were preincubated with fresh medium in the presence or absence of emodin $(10,5,2.5,1.25,0.6,0.3 \mu \mathrm{g} / \mathrm{mL})$ for $2-6 \mathrm{~h}$. The cells were then washed with PBS for twice and challenged with $100 \mathrm{TCID}_{50}$ of $\mathrm{CVB}_{4}$ for $1 \mathrm{~h}$. After virus adsorption, the cells were rinsed twice with PBS and overlaid with 2\% DMEM until typical CPE was visible. The inhibition of virus was evaluated by MTT assay.

\subsubsection{Plaque Reduction Assay}

The antiviral activity of emodin was also evaluated by a plaque reduction assay. Briefly, HEp-2 cells were seeded into 24 -well culture plates and incubated until reaching at least $95 \%$ confluence. Cells were then infected with $100 \mathrm{TCID}_{50} \mathrm{CVB}_{4}$. After $1 \mathrm{~h}$ adsorption, the cells were washed twice with pre-warmed PBS, and overlaid with $1.2 \%$ agarose $\left(42-45^{\circ} \mathrm{C}\right)$ containing complete DMEM with different concentration of emodin and ribavirin. The cells were then fixed with $10 \%$ formaldehyde for $30 \mathrm{~min}$ and stained with $1 \%$ crystal violet solution. The plaques numbers were counted by visual examination and percentage of plaque inhibition was calculated following the protocols described elsewhere.

\subsubsection{Time of Addition Assay}

Time of addition assay was performed as described elsewhere [23]. Briefly, HEp-2 cells were seeded into 12-well culture plates (Costar) at a density of $2 \times 10^{5}$ cells/well for $24 \mathrm{~h}$. Cell monolayers were then infected with $100 \mathrm{TCID}_{50} \mathrm{CVB}_{4}$ at $4{ }^{\circ} \mathrm{C}$ for $1 \mathrm{~h}$. The unbound virus was removed from the monolayers with PBS for three times. Emodin $(37 \mu \mathrm{M})$ or ribavirin $(512 \mu \mathrm{M})$ was added into wells concurrently with $\mathrm{CVB}_{4}$ infection $(0 \mathrm{~h})$ or at intervals of $2,4,6,8,10$ and $12 \mathrm{~h}$ after infection. The virus titers were determined by plaque assay as described previously. 


\subsubsection{Quantification of $\mathrm{CVB}_{4}$ RNA Level}

Total RNAs were isolated using TRIzol Reagent (Invitrogen, Carlsbad, CA, USA) according to manufacturer's instructions. Random primer (Sangon, Shanghai, China) was used for reversed transcription of the total RNA by M-MLV reverse transcriptase (Promega, Beijing, China). cDNAs obtained from reverse transcription were stored at $-20{ }^{\circ} \mathrm{C}$. Primer pairs referred to reference [24] are listed as following (130 bp): $\mathrm{CVB}_{4}$ forward primer 5'-GTAGTCCTCCGGCCCCT-3'; reverse primer 5'-AATTGTCACCATAAGCAGCCA-3'.GAPDH (122bp) forward primer 5'-TCATTGACCTCA ACTACATGGTTT-3'; reverse primer 5'-GAAGATGGTGATGGGATTTC-3'. The reaction was performed on a Bio-Rad CFX96 instrument using SYBR Green Real-time PCR Master Mix Reagent (Toyobo, Japan). Each real-time PCR reaction was performed by initial denaturation at $95{ }^{\circ} \mathrm{C}$ for $3 \mathrm{~min}$, then a three-step cycle procedure (denaturation, $95{ }^{\circ} \mathrm{C} 10 \mathrm{~s}$; annealing, $55{ }^{\circ} \mathrm{C} 10 \mathrm{~s}$; extension, $72{ }^{\circ} \mathrm{C}$ $30 \mathrm{~s}$ ) for 40 cycles, $95{ }^{\circ} \mathrm{C} 10 \mathrm{~s}, 65{ }^{\circ} \mathrm{C} 5 \mathrm{~s}$, end. All the reactions were performed in triplicate and the results were normalized to GAPDH. The fluorescence emission of each cycle was monitored and analyzed using Bio-Raid CFX manger software.

\subsubsection{Detection of Apoptosis by Flow Cytometry}

The apoptotic cells were assessed by flow cytometry using Annexin-V/propidium iodide (PI) apoptotic kit according to manufacturer's protocol (Promega). In brief, Hep-2 cells infected with $\mathrm{CVB}_{4}$ were treated with emodin for $48 \mathrm{~h}$. Floating cells were collected and centrifuged at $500 \mathrm{~g}$ for $10 \mathrm{~min}$. Cells pellets were washed twice with ice cold PBS, resuspended in $500 \mu \mathrm{L} 1 \times$ binding buffer containing $5 \mu \mathrm{L}$ FITC-conjugated annexin-V antibody and $8 \mu \mathrm{L}$ of PI $(5 \mu \mathrm{g} / \mathrm{mL})$ for $10 \mathrm{~min}$ at room temperature in the dark. Apoptotic cells were determined by flow cytometry and the data were analyzed using Cell Quest software (EPICS ALTRA II, Beckman, Brea, CA, USA).

\subsection{Experiments in Vivo}

\subsubsection{Experimental Design and Tissue Sampling}

BALB/c mice were purchased from the Animal Research Center of Wuhan University (Certificate No. SCXK 2008-0004, Hubei, China). Mice were handled in accordance with guidelines approved by the Institutional Animal Care and Use Committee (Wuhan, China). Ninety male BALB/c mice of $4 \sim 6$ weeks in age were randomly divided into six groups. Mice were infected by intraperitoneal injection with $0.2 \mathrm{~mL}$ saline containing $10 \mathrm{LD}_{50}$ of $\mathrm{CVB}_{4}$. Mice were orally administered with the indicated doses $(30,15,7.5 \mathrm{mg} / \mathrm{kg} / \mathrm{d})$ of emodin or $10 \mathrm{mg} / \mathrm{kg} / \mathrm{d}$ ribavirin for 14 consecutive days, respectively. Saline $(0.9 \%)$ was used in normal and viral controls. Body weight and death were recorded each day. Eight mice from each group were sacrificed on days 7 and 14 after viral inoculation. The cardiac index was expressed as the ratio of mean heart weight to mean body weight. The heart was divided into two parts, one part was homogenized in DMEM to determine virus titers by plaque assay, and the other was fixed for further histological examinations. Histopathological features of myocarditis, including necrosis and inflammation were graded by a semiquantitative score from 0 to $4(0=$ no necrosis or inflammation, 
$1=1 \sim 10$ foci of necrosis or inflammation per section, $2=11 \sim 20$ foci, $3=21 \sim 40$ foci, $4=$ over 40 foci or confluent areas of necrosis).

\subsubsection{Apoptosis-Related Genes Isolation and Real-Time RT-PCR}

Total RNAs were extracted with Trizol reagent from heart (Invitrogen) and reverse transcripted into cDNA, according to the manufacturer's protocol. Primers were designed by Primer Premier 5 software and listed as follows: caspase-3: 5'-TGAGGCGGTTGTAGAAGAG-3', 5'-TAATGAGAATGGGGG AAGA-3'; Bcl-2: 5'-GATTGATGGGATCGTTGCCTTA-3', 5'-CCTTGGCATGAGATGCAGGA-3'. After an initial denaturation step at $94{ }^{\circ} \mathrm{C}$ for $3 \mathrm{~min}$, a three-step cycle procedure was carried out (denaturation, $95^{\circ} \mathrm{C}, 15 \mathrm{~s}$; annealing, $58^{\circ} \mathrm{C}, 15 \mathrm{~s}$; and extension, $72{ }^{\circ} \mathrm{C}, 40 \mathrm{~s}$ ) for 40 cycles. All reactions were performed in at least duplicate for each sample. The relative mRNA expressions were normalized to the level of GAPDH and were calculated using the formula as described elsewhere [25].

\subsubsection{Immunoblot Analysis}

Infected cardiac muscle tissues, either untreated or with different treatment, were cut and centrifuged at $3,000 \times \mathrm{g}$ at $4{ }^{\circ} \mathrm{C}$ for $5 \mathrm{~min}$. The remaining tissues were homogenated for $30 \mathrm{~s}$ in lysis buffer at $0{ }^{\circ} \mathrm{C}$ and centrifuged at $12,000 \times \mathrm{g}$ at $4{ }^{\circ} \mathrm{C}$ for $10 \mathrm{~min} .400 \mu \mathrm{L}$ supernate were mixed with $5 \times$ loading buffer , boiled for $5 \mathrm{~min}$, then centrifuged at $12,000 \times \mathrm{g}$ at $4{ }^{\circ} \mathrm{C}$ for $10 \mathrm{~min}$. The resulting supernatants were loaded on a 12\% SDS-polyacrylamide gel for electrophoresis and transferred to nitrocellulose membranes. Membranes were blocked with $5 \%$ dry milk solution at $4{ }^{\circ} \mathrm{C}$ overnight and washed twice with trans-buffer (without methanol) before incubated with antibodies against mouse caspase-3, rabbit anti-Bcl-2 and mouse anti-GAPDH (Beyotime Institute of Biotechnology, Co., Ltd., Nanjing, China). The membranes were washed and incubated with horseradish peroxidase-conjugated secondary antibodies in blocking solution. Protein bands were visualized with an enhanced chemiluminescence (ECL) detection system.

\subsection{Statistical Analysis}

Each set of experiments was repeated at least three times with consistent results. The data were analyzed by SPSS 13.0 software (SPSS Inc., Chicago, IL, USA). The data of in vitro experiments was analyzed using Student's t-test, and that of in vivo experiments was analyzed using Log-rank test for survival rates, analysis of variance (ANOVA) for MTD and Kaplan-Meier method for survival analysis. A $p$-value of $<0.05$ was considered statistically significant.

\section{Conclusions}

Our results demonstrated the potent antiviral activity of emodin by inhibiting $\mathrm{CVB}_{4}$ entry and replication, especially during the first $0-4 \mathrm{~h}$ postinfection. Our results also implied that emodin may act as a biological synthesis inhibitor against $\mathrm{CVB}_{4}$ infection rather than directly inactivating the viruses or blocking their absorption to the susceptible cells. The inhibitory effect of emodin on $\mathrm{CVB}_{4}$ replication further confirmed by qPCR assay was equivalent that of the conventional antiviral ribavirin. Ribavirin, a synthetic nucleoside, structurally related to inosine and guanosine, can induce lethal mutations when it 
is incorporated into viral RNA. The antimicrobial mechanisms of emodin, however, are still largely unknown. Previous studies have revealed that emodin may directly inhibit host cell casein kinase 2 (CK2), which is essential for the phosphorylation of some viral proteins [26,27]. Moreover, the antiviral capacity of emodin against enveloped viruses is due to its affinity for phospholipid membrane and weakeness for hydrophobic interactions between hydrocarbon chains in phospholipid bilayers $[13,19]$. Emodin can also inhibit the $3 \mathrm{a}$ ion channel of coronavirus SARS-CoV and HCoV-OC43 as well as virus release from $\mathrm{HCoV}-\mathrm{OC} 43$ with a $\mathrm{K}_{1 / 2}$ value of about $20 \mu \mathrm{M}$ [16]. And emodin may exert its antiviral activity by direct inhibiting UL12 alkaline nuclease activity of HSV-1 [14,28]. These findings suggest that emodin may be a potential antiviral candidate with a broad spectrum of antiviral activities by targeting viruses or virus-related proteins. Apoptosis may play a primary role in the pathogenesis during viral infection. In our study, emodin could also mitigate $\mathrm{CVB}_{4}$-induced apoptosis in vitro and in vivo. The rate of apoptosis in HEp-2 cells treated with emodin $(18.5,9 \mu \mathrm{M})$ was significantly lower than that of virus infected controls. There were no differences between $18.5 \mu \mathrm{M}$ emodin and $512 \mu \mathrm{M}$ ribavirin in inhibiting $\mathrm{CVB}_{4}$ apoptosis. Furthermore, emodin could down-regulate the apoptosis-promoting gene caspase- 3 while up-regulate the apoptosis-inhibiting gene Bcl-2 in murine heart tissues. In vivo orally administered emodin at $30,15,7.5 \mathrm{mg} / \mathrm{kg} / \mathrm{d}$ significantly improved mice survival rate, prolonged the MTD, decreased HW/BW, virus titers and myocardial pathologic scores caused by virus infection. 30, $15 \mathrm{mg} / \mathrm{kg} / \mathrm{d}$ emodin treatment was equivalent to $10 \mathrm{mg} / \mathrm{kg} / \mathrm{d}$ ribavirin in alleviating the virus myocardial lesions. These properties added further appeal to emodin as a potential therapeutic agent against $\mathrm{CVB}_{4}$ infection and therewith associated myocarditis.

\section{Acknowledgments}

The financial assistance given by the National Mega Project on Major Drug Development (No. 2009ZX09301-014-1) and National Natural Science Foundation of China (NSFC Project No. 81371865) are gratefully acknowledged.

\section{Conflicts of Interest}

The authors declare no conflict of interest.

\section{References}

1. Crowell, R.L.; Landau, B.J. A short history and introductory background on the coxsackieviruses of group B. Curr. Top. Microbiol. Immunol. 1997, 233, 1-11

2. Modlin, J.F.; Rotart, H.A. Group B coxsackie disease in children. Curr. Top. Microbiol. Immunol. 1997, 233, 54-80.

3. Rotbart, H.A. Treatment of picornavirus infections. Antiviral Res. 2002, 53, 83-98.

4. Pallansch, M.A. Coxsackievirus B epidemiology and public health concerns. Curr. Top. Microbiol. Immunol. 1997, 233, 13-30.

5. Carrasco, L. Picornavirus inhibitors. Pharmacol. Ther. 1994, 64, 215-290. 
6. Heim, A.; Grumbach, I.; Pring-Akerblom, P.; Stille-Siegener, M.; Müller, G.; Kandolf, R.; Figulla, H.R. Inhibition of coxsackievirus B3 carrier state infection of cultured human myocardial fibroblasts by ribavirin and human natural interferon-alpha. Antiviral Res. 1997, 34, 101-111.

7. Kishimoto, C.; Crumpacker, C.S.; Abelmann, W.H. Ribavirin treatment of murine coxsackievirus B3 myocarditis with analyses of lymphocyte subsets. J. Am. Coll. Cardio. 1988, 12, 1334-1341.

8. Feigelstock, D.A.; Mihalik, K.B.; Feinstone, S.M. Selection of hepatitis C virus resistant to ribavirin. Virol. J. 2011, 8, 402.

9. Nomura, H.; Tanimoto, H.; Kajiwara, E.; Shimono, J.; Maruyama, T.; Yamashita, N.; Nagano, M.; Higashi, M.; Mukai, T.; Matsui, Y.; et al. Factors contributing to ribavirin-induced anemia. J. Gastroenterol. Hepatol. 2004, 19, 1312-1317.

10. De Clercq, E. Antiviral drugs in current clinical use. J. Clin. Virol. 2004, 30, 115-133.

11. Heo, S.K.; Yun, H.J.; Park, W.H.; Park, S.D. Emodin inhibits TNF-alpha-induced human aortic smooth muscle cell proliferation via caspase and mitochondrial-dependent apoptosis. J. Cell. Biochem. 2008, 105, 70-80.

12. Kuo, Y.C.; Tsai, W.J.; Meng, H.C.; Chen, W.P.; Yang, L.Y.; Lin, C.Y. Immune reponses in human mesangial cells regulated by emodin from Polygonum hypoleucum Ohwi. Life Sci. 2001, 68, 1271-1286.

13. Alves, D.S.; Pérez-Fons, L.; Estepa, A.; Micol, V. Membrane-related effects underlying the biological activity of the anthraquinones emodin and barbaloin. Biochem. Pharmacol. 2004, 68, 549-561.

14. Hsiang, C.Y.; Ho, T.Y. Emodin is a novel alkaline nuclease inhibitor that sup-presses herpes simplex virus type 1 yields in cell cultures. Br. J. Pharmacol. 2008, 155, 227-235.

15. Shuangsuo, D.; Zhengguo, Z.; Yunru, C.; Xin, Z.; Baofeng, W.; Lichao, Y.; Yan'an, C. Inhibition of the replication of hepatitis B virus in vitro by emodin. Med. Sci. Monit. 2006, 12, BR302-BR306.

16. Schwarz, S.; Wang, K.; Yu, W.; Sun, B.; Schwarz, W. Emodin inhibits current through SARS-associated coronavirus 3a protein. Antiviral Res. 2011, 90, 64-69.

17. Dang, S.; Zhang, X.; Song, P.; Bian, J.; Cheng, Y. Inhibition on hepatitis B virus by emodin and astragalus polysaccharides in vitro. J. Xi'an Jiaotong Univ. Med. Sci. 2007, 28, 521-525.

18. Andersen, D.O; Weber, N.D.; Wood, S.G.; Hughes, B.G.; Murray, B.K.; North, J.A. In vitro virucidal activity of selected anthraquinones and anthraquinone derivatives. Antiviral Res. 1991, 16, 185-196.

19. Sydiskis, R.J.; Owen, D.G.; Lohr, J.L.; Rosler, K.H.; Blomster, R.N. Inactivation of enveloped viruses by anthraquinones extracted from plants. Antimicrob. Agents Chemother. 1991, 35, 2463-2466.

20. Adrian, F.R. A left superior vena cava draining the blood from a closed coronary sinus. J. Anat. 1938, 73, 195-197.

21. Shi, L.; Xiong, H.; He, J.; Deng, H.; Li, Q.; Zhong, Q.; Hou, W.; Cheng, L.; Xiao, H.;Yang, Z. Antiviral activity of arbidol against influenza A virus, respiratory syncytial virus, rhinovirus, coxsackie virus and adenovirus in vitro and in vivo. Arch. Virol. 2007, 152, 1447-1455. 
22. Xiong, H.R.; Luo, J.; Hou, W.; Xiao, H.; Yang, Z.Q. The effect of emodin, an anthraquinone derivative extracted from the roots of Rheum tanguticum, against herpes simplex virus in vitro and in vivo. J. Ethnopharmacol. 2011, 133, 718-723.

23. Ling, J.X.; Wei, F.; Li, N.; Li, J.L.; Chen, L.J.; Liu, Y.Y. Amelioration of influenza virus-induced reactive oxygen species formation by epigallocatechin gallate derived from green tea. Acta Pharmacol. Sin. 2012, 33, 1533-1541.

24. Brilot, F.; Jaïdane, H.; Geenen, V.; Hober, D. Coxsackievirus B4 Infection of Murine Foetal Thymus Organ Cultures. J. Med. Virol. 2008, 80, 659-666.

25. Wei, F.; Li, J.L.; Ling, J.X.; Chen, L.J.; Li, N.; Liu, Y.Y. Establishment of SYBR green-based qPCR assay for rapid evaluation and quantification for anti-Hantaan virus compounds in vitro. Virus Genes 2013, 46, 54-62.

26. Kluck, R.M.; Bossy-Wetzel, E.; Green, D.R.; Newmeyer, D.D. The release of cytochrome c from mitochondria: A primary site for Bcl-2 regulation of apoptosis. Science 1997, 275, 1132-1136.

27. Battistutta, R.; Sarno, S.; de Moliner, E.; Papinutto, E.; Zanotti, G.; Pinna, L.A. The replacement of ATP by the competitive inhibitor emodin induces conformational modifications in the catalytic site of protein kinase CK2. J. Biol. Chem. 2000, 275, 29618-29622.

28. Ho, T.Y.; Wu, S.L.; Chen, J.C.; Li, C.C.; Hsiang, C.Y. Emodin blocks the SARS coronavirus spike protein and angiotensin-converting enzyme 2 interaction. Antiviral Res. 2007, 74, 92-101.

Sample Availability: Samples of the compounds of emodin and ribavirin are available from the authors.

(C) 2013 by the authors; licensee MDPI, Basel, Switzerland. This article is an open access article distributed under the terms and conditions of the Creative Commons Attribution license (http://creativecommons.org/licenses/by/3.0/). 